\title{
EVALUATION OF WORK METHODS FOR PRODUCTION OF SOLID BIOFUEL FROM HARVESTING RESIDUES IN COMMERCIAL THINNING OF CONIFEROUS FORESTS
}

\author{
Andis Lazdins, Edgars Iecelnieks, Agris Zimelis, Gints Spalva \\ Latvian State Forest Research Institute "Silava", Latvia \\ andis.lazdins@silava.lv, e.iecelnieks@inbox.lv, agris.zimelis@silava.lv, gints.spalva@silava.lv
}

\begin{abstract}
The scope of the study is the development and validation of a working method for the production of solid biofuel from harvesting residues in the commercial thinning before the final felling, including the elaboration of recommendations for arranging of harvesting residues and round-wood logs between the remaining trees. According to the study results, biofuel production in commercial thinning does not impair the productivity of the harvesting and forwarding, but it is necessary to take into account the possible additional working time consumption to move harvesting residues into strip-roads, if the ground bearing conditions would significantly deteriorate before forwarding. The recommended method of biofuel production from harvesting residues considers felling of trees growing on the strip-road at approximately 45-90 degree angles to the direction of movement of the harvester. After felling trees on the strip-roads, harvesting on harvesting sectors should be designed in perpendicular to the direction of movement of the harvester. The sector shall be divided into 2 zones. The first zone is up to $6 \mathrm{~m}$ from the longitudinal axis of the strip-roads. The trees in the $1^{\text {st }}$ zone are felled in the direction of the strip-road, planning to leave the logging residues on the strip-roads, whereas in the $2^{\text {nd }}$ the trees are felled from themselves and logging residues are piled between roundwood logs. Depending on the overgrowth of the strip-roads, using this method, the share of logging residues available for the biofuel production will be $30-50 \%$ of the total quantity of logging residues. In total $424 \mathrm{~m}^{3}\left(120-160 \mathrm{~m}^{3}\right.$ per method) of roundwood assortments were produced during the time studies, the estimated amount of harvesting residues produced during the trial is $18 \mathrm{~m}^{3}$ in average per method.
\end{abstract}

Keywords: commercial thinning, harvesting residues, biofuel, work method.

\section{Introduction}

The increase in logging intensity in harvesting fells indicates the need to review the assumptions underlying the inefficiency of production of harvest in commercial felling, and to assess the feasibility of biofuel preparation, including the available resources, technical solutions and production costs. The amount of logging residues available in commercial thinning during the last five years corresponds to an average of 136 thousand tons of dry matter (DM). Biomass recalculation equations [1;2] developed by J. Liepinšs, using white alder, black alder, oak, ash and other aspen equations for tree species are used in the calculations.

Part of the logging residues should be used to improve the soil bearing capacity on strip-roads, some of the residues will be lost during production, i.e. extraction of these residues would not be economically viable or would significantly impair the quality of the biofuel. In the calculations of the available resource it is assumed that at least $10 \mathrm{~kg}$ of dry matter per $\mathrm{m}^{2}$ logging residue [3-5] is needed to improve the bearing capacity of strip-roads (SR), but the area of SR is $20 \%$ of the area of the forest stand [6]. Technological losses are $30 \%$ of the biomass available for preparation of biofuel, according to the average values in final felling $[7 ; 8]$.

It is more difficult to assess the need to use logging residues to improve the bearing capacity in SR, because the State Forest Service does not publish statistics on distribution of logging by forest types, logging season and felling type. The calculations use assumptions on the probability of commercial thinning applied in the forest reference level depending on the forest type [9] referring to the average of the last five years. It is assumed in the calculation that in forests on wet and drained soils the residues should be always used in SR (at least $10 \mathrm{~kg} \mathrm{~m}^{-2}$ of dry matter), but in other stand types (66\% of the commercial thinning area during the recent five years) all logging residues can be extracted. According to this calculation, the production potential of biofuel has gradually increased in state forests since 2000, reaching 63 ktonnes DM yr. on average during the last five years. It should be noted that this calculation does not take into account the seasonality of logging, which can significantly affect accessibility of the resources. Biofuel production potential in state forests according to the applied method is 378 thousand $\mathrm{m}^{3}$ loose volume (LV) yr., $36 \mathrm{LV} \mathrm{m}^{3} \cdot \mathrm{ha}^{-1}$ in average. Both parameters increased significantly since 2000 (Fig. 1). 


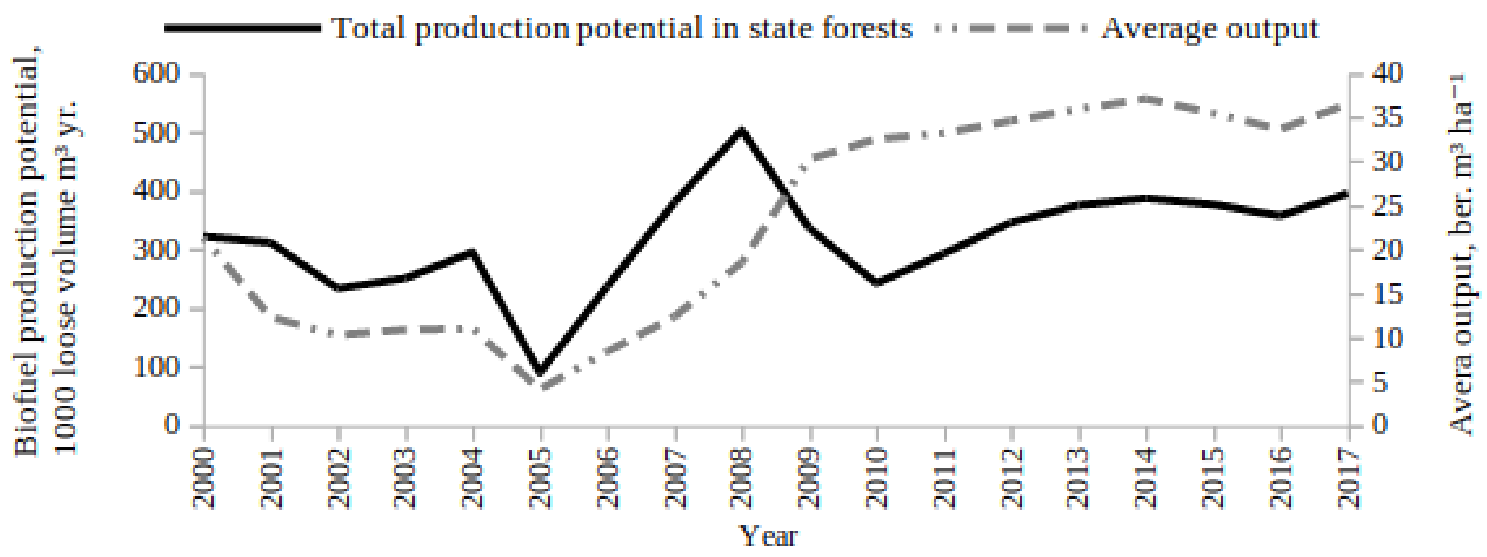

Fig. 1. Biofuel production potential in commercial thinning in state forests in Latvia in 2000-2017

\section{Materials and methods}

The trials were implemented in spring 2018. Suitable stands on dry sandy mineral soils, where harvesting residues can be collected without risk of significant increase of soil and tree damages, were selected for the studies. The stand parameters were determined before and after felling, using the same permanent network of plots. The damaged remaining trees were estimated separately after harvesting and forwarding. In both cases, the records were made after completion of the works. Damages are counted according to their location in the SR [6;10]. In order to exclude the effect of undergrowth on productivity in the areas prepared for the work methods 1 and 3 undergrowth trees were extracted before logging, respectively, all trees with the diameter of less than $8 \mathrm{~cm}$ are cut with a chain saw; in the areas prepared for the method 2, undergrowth trees with the diameter below $3 \mathrm{~cm}$ are extracted. Operators were trained before the studies by the instructor of operators of forest machines from the company "Forest and Wood Products Research and Development". The instructor evaluated the conformity of the operators' skills to the trial, as well as, if necessary, trained according to the research methods. Timber production was carried out according to the quality requirements of JSC "Latvijas valsts meži” [11-13].

The work methods evaluated in the study are based on the experience of the previously implemented trials [6;14-17]. Using the standard method (No. 1) logging residues were left in SR. In the standard method trees are harvested at an angle of about 45 degrees or perpendicular to the longitudinal axis of the corridor to form a steady stack of logs. Logging residues are moved to SR. The selection of trees to cut begins with the trees on the SR, but no more than $5 \mathrm{~m}$ in the planned direction of the harvester movement. Relocation of the harvester position should be planned regularly with a travel distance of 0.3 to $1 \mathrm{~m}$. Extraction should be planned according to the local conditions; cutting of trees on SR either 45-90 degrees to the longitudinal axis of the SR, thus ensuring that the assortments are stacked in compact piles. After cutting the trees on the SR harvesting should be planned on the right or left side of the harvester by creation of a manipulator working sector, which is split into 2 parts - the nearest area (0-6 $\mathrm{m}$ from the longitudinal axis of SR) and distal work sector (6-10 $\mathrm{m}$ from the longitudinal axis of SR). In the nearest and the distal work sector residues are left in stand or loaded into SR. When harvesting in the distal sector is completed the manipulator is moved to another side to continue with the next work sector on other sector. Biomass method (No. 2) differs from the standard method by production of biofuel from undergrowth trees and tops. Biofuel from tops and small trees is produced in all the nearest and distal sectors and on SR. Harvesting residues are left in stand or moved to strip roads. Biofuel is piled along with other roundwood assortments. Logging residues (No. 3) method does not consider production of partially delimbed biofuel from tops and small trees. Harvesting residues and remaining undergrowth trees are collected in from the distal sectors (6-10 m from the longitudinal axis of SR) piled behind roundwood assortments. In total $424 \mathrm{~m}^{3}$ (120-160 $\mathrm{m}^{3}$ per method) of roundwood assortments were produced during the harvesting time studies, the estimated amount of harvesting residues produced during the trial is $18 \mathrm{~m}^{3}$ in average per method. 55 loads (14-25 loads per method) were extracted during the studies. 


\section{Results and discussion}

Four stands were extracted in the trials including 1 spruce stand and 3 pine stands. The forest stand data in the test areas before logging are shown in Table 1.

Table 1

Stand inventory data before thinning

\begin{tabular}{|l|c|c|c|c|c|c|}
\hline Stand ID & $\begin{array}{c}\text { Dominant } \\
\text { species }\end{array}$ & $\begin{array}{c}\text { No of trees } \\
\text { per ha }\end{array}$ & $\begin{array}{c}\text { Diameter at 1.3 } \\
\mathbf{m} \text { height, cm }\end{array}$ & $\begin{array}{c}\text { Tree } \\
\text { height, } \mathbf{~ m}\end{array}$ & $\begin{array}{c}\text { Basal area, } \\
\mathbf{m}^{\mathbf{2}} \mathbf{h a}^{-\mathbf{1}}\end{array}$ & $\begin{array}{c}\text { Growing stock, } \\
\mathbf{m}^{\mathbf{3}} \mathbf{h a}^{-\mathbf{1}}\end{array}$ \\
\hline $506-138-22$ & Spruce & 973 & 19.2 & 21.5 & 34 & 427 \\
\hline $506-138-23$ & Pine & 1187 & 17.2 & 19.7 & 33 & 386 \\
\hline $506-138-24$ & Pine & 1200 & 18.8 & 20.0 & 40 & 479 \\
\hline $506-138-25$ & Pine & 955 & 18.1 & 20.6 & 28 & 321 \\
\hline
\end{tabular}

Comparing the pre-and post-harvesting stand data, it was found that $52 \%$ of the trees with an average diameter of more than $4 \mathrm{~cm}$ were cut during the commercial thinning. The diameter of the average tree after thinning increased by $34 \%$, height - by $14 \%$. The extracted basal area in average was $20 \%$ and the extracted stock $-21 \%$ in comparison to the initial parameters. According to the survey data $74 \mathrm{~m}^{3} \mathrm{ha}^{-1}$ was extracted on average. No difference was found between the work methods. Time studies were done from 26 to 29 November, 2018. The total duration of the time studies was 22.5 hours. During the rest of the time, logging was carried out in additional stands to improve the skills of the operators in application of biofuel production work methods.

The average diameter of an extracted tree $(11.9 \mathrm{~cm})$ is smaller, while working with the $2^{\text {nd }}$ method, but the difference is not statistically significant. This is associated with a different approach in extraction of undergrowth trees. While working with the $1^{\text {st }}$ and $3^{\text {rd }}$ method, the average diameter of the sawn trees does not differ significantly. The distribution of sawn trees by species does not significantly differ depending on the work methods. On average, 5.8 trees are necessary to prepare $1 \mathrm{~m}^{3}$ of $\operatorname{logs}$ with bark. Except for losses the average biomass of the branches is $64 \mathrm{~kg} \cdot \mathrm{m}^{-3}$ $\left(0.4 \mathrm{~m}^{3} \cdot \mathrm{m}^{-3}\right)$.

On average, 117 trees were processed in a productive hour, a slightly bigger number, while working with the method 3 and smaller - working with the $1^{\text {st }}$ method. The average productivity in the trials was $20.1 \mathrm{~m}^{3}$ per productive hour. The highest average productivity was found, while working with the $3^{\text {rd }}$ method (Table 2), however, the difference is not significant. Harvester productivity indicators obtained from the harvester files did not differ significantly from the values obtained in the time studies.

Table 2

Summary of harvesting productivity

\begin{tabular}{|c|c|c|}
\hline Work method & $\begin{array}{c}\text { No of trees extracted per } \\
\text { productive hour }\end{array}$ & $\begin{array}{c}\text { Productivity, } \mathbf{~ m}^{\mathbf{3}} \text { per productive } \\
\text { hour }\end{array}$ \\
\hline 1 & 112 & 21.6 \\
\hline 2 & 118 & 17.4 \\
\hline 3 & 126 & 22.5 \\
\hline
\end{tabular}

Comparing the labour productivity of processing trees of the same size by different methods, no significant difference was found between the $1^{\text {st }}$ and $2^{\text {nd }}$, and the $1^{\text {st }}$ and $3^{\text {rd }}$, but the productivity indicators of the $2^{\text {nd }}$ and $3^{\text {rd }}$ method differ significantly. The $3^{\text {rd }}$ working method in the study demonstrated better productivity. The harvesting productivity depending on the diameter of the tree can be characterized by power equations (Fig. 2).

Forwarding time studies were done during transportation of roundwood logs, between December 5 and 14, 2018. Harvesting residues were used in strip-roads due to deterioration of the work conditions during the studies. The soil bearing capacity was also significantly impaired by the 
choice of the operators not to use tracks at the beginning. The tracks were only installed after the depth of the ruts reached a critical level and there were no residues left to put into ruts.

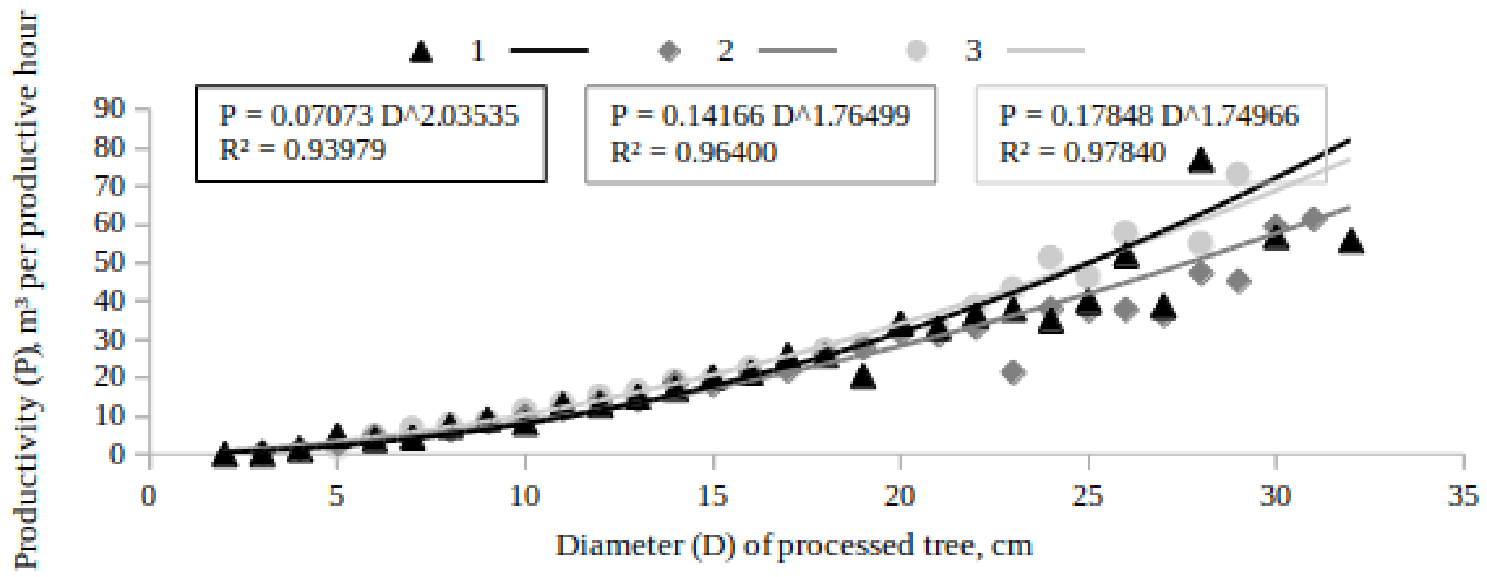

\section{Fig. 2. Relation between productivity and diameter of extracted trees and work method}

Using the $1^{\text {st }}$ working method, the forwarder operator did not use time to pack residues into striproads, because it was already done by the harvester operator, therefore, the productive time per load was smaller in the trials, if the $1^{\text {st }}$ working method was used.

On average, 5 loads were delivered from each corridor (3.3 loads per $100 \mathrm{~m}$ a corridor). The average amount of timber taken from each corridor is $41 \mathrm{~m}^{3}$, with a maximum of $59 \mathrm{~m}^{3}$. In such conditions in case of timely installation of tracks putting of logging residues into SR would be necessary only in severe forwarding conditions [18,19]. This means that the main reason for deterioration of the soil bearing capacity, when working with the $2^{\text {nd }}$ and $3^{\text {rd }}$ method, was late installation of tracks.

Relatively larger forwarder loads were in the areas, where $3^{\text {rd }}$ method was used. Perhaps, this is due to the fact that in this trial the deployment of tracks on the rear axle was started immediately. This method also had the longest forwarding distance $(256 \mathrm{~m})$. The average forwarding distance for the trials was $185 \mathrm{~m}$. The transported volume is determined according to the data provided by the operators, i.e. logs with bark for firewood and without bark for other types of logs. The drive speed was relatively higher also while the $3^{\text {rd }}$ work method was used, but it is associated with better driving conditions rather than the work method selection.

According to the productivity calculation, the least amount of the working time, including loading, has been consumed, when working with the $3^{\text {rd }}$ method. The unloading time did not differ, regardless of the working method used. A statistically significant difference between the methods was found for the operation "improvement of driving conditions" (putting residues into SRs). The smallest time consumption for this operation was observed, if the $1^{\text {st }}$ method was used. There were no statistically significant differences between the work methods for other work time elements. Obviously, the difference in productivity between the methods is the result of the cumulative effect associated with the change in the work method and the equipment (tracks) resulting in bigger loads.

The most of the work time (56\%) is spent by the forwarder operator to grab and load in logs, as well as to drive in the stand and for other unpredicted operations. Comparing the productivity during the trial, a steady increase was found, respectively, changes in the productivity indicators may be related to an increase in the professional skills of the operators rather than the logging method.

Summary of the forwarder performance indicators is given in Table 3. On average, 1.2 loads ( 5.9 min. per $\mathrm{m}^{3}$ ) can be loaded and unloaded per productive hour.

The study does not provide data on the productivity of forwarding of harvesting residues, so trials should be continued in optimal conditions ensuring that tracks are installed timely to avoid deterioration of the forwarding conditions. The experience gained in the study confirms the mandatory need to use tracks in commercial thinning in order not to impair the soil bearing capacity and to avoid significant soil damages. 
Summary of forwarding productivity, $\min . \mathrm{m}^{-3}$

\begin{tabular}{|c|c|c|c|c|}
\hline Work method & Loading & Unloading & Driving in stand & Productive time \\
\hline 1 & 4.6 & 1.1 & 1.0 & 6.6 \\
\hline 2 & 5.4 & 1.2 & 1.0 & 7.6 \\
\hline 3 & 4.0 & 1.2 & 1.2 & 6.4 \\
\hline
\end{tabular}

According to the biomass calculations, on average $1 \mathrm{~m}^{3}$ of the produced logs (with bark) equals to $106 \mathrm{~kg} \mathrm{DM}$ of harvesting residues. The reduction of growing stock during felling was $74 \mathrm{~m}^{3} \cdot \mathrm{ha}^{-1}$, respectively, the total amount of logging residues produced is 7.8 tonnes DM ha ${ }^{-1}$. At least 20 tonnes of material are required in SR to ensure at least $10 \mathrm{~kg} \mathrm{~m}^{-2}$ of logging residues, respectively, all logging residues and low-value timber in this felling site should be applied to SR, if the improvement of the soil bearing capacity is required throughout the felling area.

The productivity of the $3^{\text {rd }}$ and, in particular, $2^{\text {nd }}$ method would increase significantly if the operator of the forwarder had no need to move logging residues to SRs.

Regardless of the logging method, all work methods had a high proportion of mechanically damaged remaining trees. The difference between the work methods is not statistically significant, although the proportion of damaged trees is smaller in the areas extracted using the $1^{\text {st }}$ and $3^{\text {rd }}$ method. The forwarder produced on average $39 \%$ of all mechanical damages. This calculation includes trees that were not previously damaged by the harvester. Higher proportion of damages ( $48 \%$ ) caused by the forwarder is in the areas extracted using the $3^{\text {rd }}$ method, but the difference is not statistically significant. The most of the damages are bark abrasions.

Planning of extraction of harvesting residues in commercial thinning could be considerably improved by utilization of depth-to-water maps [20;21] in the process of elaboration of the work order to find the optimal route and estimate the area, where harvesting residues are necessary to improve the soil bearing capacity. Biomass equations [2] should also be integrated into the planning system to give a more accurate estimate of the potential biomass output.

\section{Conclusions}

1. The objectives of the research were partly achieved - due to deterioration of the forwarding conditions, the logging residues were laid in the strip-roads. This result points to the need to use tracks in felling areas, where harvesting residues will be produced.

2. Damages to remaining trees do not differ significantly according to the work method, but this result cannot be considered as definitive due considerable deterioration of the work conditions and transportation of the residues across the stand.

3. Harvesting productivity using the work method No. 3 (residues from the $2^{\text {nd }}$ sector are extracted) does not differ significantly from the conventional method (No. 1 in the study), therefore, the method No. 3 is recommended for implementation in commercial thinning, if the planned output of harvesting residues $\left(0.4 \mathrm{LV} \mathrm{m}^{3} \mathrm{~m}^{-3}\right.$ of roundwood) is economically sufficient.

4. According to the method No. 3 the amount of residues available for biofuel production is $30-50 \%$ of the total amount of logging residues. If the method No. 2 is applied, the theoretical output of residues available for biofuel production can reach $80-100 \%$, however, this value is limited by the work conditions and space needed for placing of assortments.

5. The productivity of the $2^{\text {nd }}$ method can be significantly improved by the use the accumulation function for small-scale tree processing; however, this assumption should be verified by experimental data.

6. Forwarding productivity varies greatly, depending on the logging method, but the difference is likely to be due to an increase in the operator experience rather than the choice of the working method. 


\section{Acknowledgements}

The study is implemented within the scope of the memorandum between LSFRI Silava and Joint stock company "Latvia state forests" from 11.10.2011.

\section{References}

[1] Liepins J., Liepins K., Lazdins A., Biomass equations for the most common tree species in Latvia, in: Proceedings of Adaptation and Mitigation: Strategies for Management of Forest Ecosystems, Riga, 2015: pp. 47-50.

[2] Liepiņš J., Lazdiņš A., Liepiņš K., Equations for estimating above- and belowground biomass of Norway spruce, Scots pine, birch spp. and European aspen in Latvia, Scandinavian Journal of Forest Research. 2017, pp. 1-43.

[3] Labelle E.R., Jeager D., Poltorak B.R. Assessing the Ability of Hardwood and Softwood Brush Mats to Distribute Applied Loads, Croatian Journal of Forest Engineering. 36, 2015, pp. 227-242.

[4] Wood M.J., Carling P.A., Moffat A.J. Reduced ground disturbance during mechanized forest harvesting on sensitive forest soils in the UK, Forestry. 76, 2003, pp. 345-361.

[5] Wood M.J., Moffat A.J., Carling P.A. Improving the Design of Slash Roads Used to Reduce Soil Disturbance During Mechanised Harvesting of Coniferous Forest Plantations in the UK, International Journal of Forest Engineering. 14, 2003, pp. 11-23.

[6] AS "Latvijas valsts meži," Kopšanas ciršu rokasgrāmata (Good practice guidance for the forest thinning), Rīga, 2008, pp 112. (In Latvian)

[7] LVMI Silava, Energeétisko šķeldu ražošana no mežizstrādes atlikumiem (Production of wood chips from harvesting residues), $2^{\text {nd }}$ ed., Salaspils, 2008, 20 p. (In Latvian)

[8] Thor M., Von Hofsten H., Lundström H., Lazdāns V., Lazdiņš A., Extraction of logging residues at LVM, AS Latvijas valsts meži \& Skogforsk, Uppsala, 2006, 36 p.

[9] Šñepsts G., Kārkliņa I., Lupiķis A., Butlers A., Bārdule A., Lazdiņš A. AGM model description, LSFRI Silava, Salaspils, 2018, 98 p.

[10] AS “Latvijas valsts meži”, Norādījumi koku bojājumu novērtēšanai (Instructions for estimation of the tree damages), Rīga, 2018, 4 p. (In Latvian)

[11] SIA "Rīgas meži”", Apaļo kokmateriālu kvalitātes prasības (Roundwood quality requirements), Rīga, 2017, 33 p. (In Latvian)

[12] AS "Latvijas valsts meži”, Kvalitātes prasības koku uzmērǐšanai pēc parauglaukumu metodes (Qality requirement for measurements of trees using sample plot method), Rīga, 2018, 8 p.

[13] AS Latvijas valsts meži, Harvesteru kalibrēšanas un kontrolmērījumu vadlīnijas (Guidelines for harvester calibration and control measurements), Rīga, 2010, pp. 16.

[14]Glöde D., Sikström U. Two Felling Methods in Final Cutting of Shelterwood, Single-Grip Harvester Productivity and Damage to the Regeneration, Silva Fennica. 35, 2001, pp. 71-83.

[15]Lazdiņš A., Kalēja S., Gruduls K., Bārdulis A. Theoretical evaluation of wood for bioenergy resources in pre-commercial thinning in Latvia, in: Annual 19th International Scientific Conference Proceedings, LLU, Jelgava, 2013: pp. 4249.

[16] Melkko M. Makeri harvester, Metsäteho, 1979, 8 p.

[17] Uusitalo J.,Introduction to forest operations and technology, 2010, 287 p.

[18] Lazdinšs A., Zimelis A. Kāpurķēžu ar palielinātu virsmas laukumu izmēginājumi kokmateriālu pievešanā no krājas kopšanas cirtēm uz augsnēm ar mazu nestspēju (Trials with extended width tracks in thinngs on soil with low bearing capacity), Salaspils, 2015, 66 p. (In Latvian)

[19]Zimelis A., Kalēja S., Lazdiṇš A., Štāls T., Saule G. Atbalsta ķēěu pētījums (Forwarder track comparison), LVMI Silava, Salaspils, 2017, 28 p. (In Latvian)

[20] Ivanovs J., Lupikis A. Identification of wet areas in forest using remote sensing data, Agronomy Research. 16, 2018, pp. 2049-2055.

[21] Ivanovs J., Sietina I., Spalva G. Identification of wet areas in forest by using LiDAR based DEM, International Scientific Conference Rural Development 2017., 2017, pp. 611-615. 